University of Nebraska - Lincoln

DigitalCommons@University of Nebraska - Lincoln

Faculty Publications from the Harold W. Manter Laboratory of Parasitology

6-1985

\title{
Coccidian Parasites (Apicomplexa: Eimeriidae) of Microtus spp. (Rodentia: Arvicolidae) from the United States, Mexico, and Japan, with Descriptions of Five New Species
}

\author{
Tedman L. Vance \\ Louisiana State University \\ Donald W. Duszynski \\ University of New Mexico, eimeria@unm.edu
}

Follow this and additional works at: https://digitalcommons.unl.edu/parasitologyfacpubs

Part of the Parasitology Commons

Vance, Tedman L. and Duszynski, Donald W., "Coccidian Parasites (Apicomplexa: Eimeriidae) of Microtus spp. (Rodentia: Arvicolidae) from the United States, Mexico, and Japan, with Descriptions of Five New Species" (1985). Faculty Publications from the Harold W. Manter Laboratory of Parasitology. 161. https://digitalcommons.unl.edu/parasitologyfacpubs/161

This Article is brought to you for free and open access by the Parasitology, Harold W. Manter Laboratory of at DigitalCommons@University of Nebraska - Lincoln. It has been accepted for inclusion in Faculty Publications from the Harold W. Manter Laboratory of Parasitology by an authorized administrator of DigitalCommons@University of Nebraska - Lincoln. 


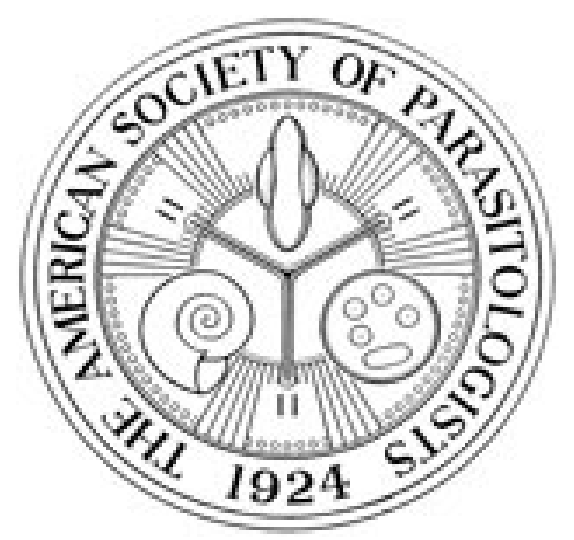

Coccidian Parasites (Apicomplexa: Eimeriidae) of Microtus spp. (Rodentia: Arvicolidae) from the United States, Mexico, and Japan, with Descriptions of Five New Species Author(s): Tedman L. Vance and Donald W. Duszynski

Source: The Journal of Parasitology, Vol. 71, No. 3 (Jun., 1985), pp. 302-311

Published by: The American Society of Parasitologists

Stable URL: http://www.jstor.org/stable/3282011

Accessed: 21/04/2010 00:43

Your use of the JSTOR archive indicates your acceptance of JSTOR's Terms and Conditions of Use, available at http://www.jstor.org/page/info/about/policies/terms.jsp. JSTOR's Terms and Conditions of Use provides, in part, that unless you have obtained prior permission, you may not download an entire issue of a journal or multiple copies of articles, and you may use content in the JSTOR archive only for your personal, non-commercial use.

Please contact the publisher regarding any further use of this work. Publisher contact information may be obtained at http://www.jstor.org/action/showPublisher?publisherCode=asp.

Each copy of any part of a JSTOR transmission must contain the same copyright notice that appears on the screen or printed page of such transmission.

JSTOR is a not-for-profit service that helps scholars, researchers, and students discover, use, and build upon a wide range of content in a trusted digital archive. We use information technology and tools to increase productivity and facilitate new forms of scholarship. For more information about JSTOR, please contact support@ jstor.org.

The American Society of Parasitologists is collaborating with JSTOR to digitize, preserve and extend access to The Journal of Parasitology. 


\title{
COCCIDIAN PARASITES (APICOMPLEXA: EIMERIIDAE) OF MICROTUS SPP. (RODENTIA: ARVICOLIDAE) FROM THE UNITED STATES, MEXICO, AND JAPAN, WITH DESCRIPTIONS OF FIVE NEW SPECIES
}

\author{
Tedman L. Vance* and Donald W. Duszynski \\ Department of Biology, The University of New Mexico, Albuquerque, New Mexico 87131
}

\begin{abstract}
Beginning in July 1980, 149 voles (Microtus spp.) representing 9 species and 14 subspecies collected in Japan, Mexico and the United States were examined for coccidia; 67 (45\%) had oocysts in their feces. These included 1 of $3(33 \%) M$. californicus sactidiegi; 0 of $1 \mathrm{M}$. longicaudus longicaudus; 0 of $1 \mathrm{M}$. l. macrurus; 48 of $111(43 \%) M$. mexicanus including 11 of $26(42 \%) M$. m. fulviventer, 1 of $2(50 \%) M$. m. fundatus, 13 of 31 (42\%) M. m. mexicanus, 1 of 4 (25\%) M. m. mogollonensis and 22 of $48(46 \%) M . m$. subsimus; 5 of $8(63 \%)$ M. montanus arizonensis; 6 of 6 M. montebelli montebelli; 2 of 4 (50\%) M. oregoni oregoni; 5 of 13 (38\%) M. pennsylvanicus pennsylvanicus; 0 of $1 \mathrm{M}$. quasiater and 0 of $1 \mathrm{M}$. townsendii townsendii. The following coccidians were identified from infected voles: Eimeria saxei n. sp. (syn. E. wenrichi "B") from M. c. sactidiegi; E. ochrogasteri, E. saxei, E. wenrichi (syn. E. wenrichi “A”), and Eimeria sp. from M. M. fulviventer, Eimeria sp. from M. m. fundatus; E. ochrogasteri, E. saxei, Eimeria tolucadensis n. sp., E. wenrichi, and Eimeria sp. from M. m. mexicanus; E. wenrichi from M. m. mogollonensis; Eimeria coahuiliensis n. sp., E. saxei, Eimeria subsimi n. sp., E. wenrichi, Eimeria sp., and Isospora mexicanasubsimi n. sp. from M. m. subsimus; E. tamiasciuri and $E$. wenrichi from $M . m$. arizonensis; Eimeria spp. from M. m. montebelli; E. saxei and E. wenrichi from $M$. o. oregoni; and $E$. ochrogasteri and $E$. wenrichi from $M$. p. pennsylvanicus. Sporulated oocysts of Eimeria coahuiliensis $\mathrm{n}$. sp. were ellipsoid, $29.6 \times 19.6(27-34 \times 18-22) \mu \mathrm{m}$ with ovoid sporocysts $14.4 \times 8.9(13-18 \times$ 8-10) $\mu \mathrm{m}$. Sporulated oocysts of Eimeria saxei n. sp. were subspheroid, $13.0 \times 11.0(11-14 \times 10-12) \mu \mathrm{m}$ with ovoid sporocysts $7.5 \times 4.0(6-9 \times 4-5) \mu \mathrm{m}$. Sporulated oocysts of Eimeria subsimi n. sp. were ovoid/subspheroid, $25.1 \times 18.7(22-28 \times 17-21) \mu \mathrm{m}$ with ellipsoid sporocysts $13.9 \times 7.4(13-15 \times 6-8) \mu \mathrm{m}$. Sporulated oocysts of Eimeria tolucadensis $\mathrm{n}$. sp. were subspheroid, $25.4 \times 20.3(23-26 \times 19-23) \mu \mathrm{m}$ with ellipsoid sporocysts $11.3 \times 7.8(10-13 \times 7-9) \mu \mathrm{m}$. Sporulated oocysts of Isospora mexicanasubsimi $\mathrm{n}$. sp. were subspheroid, $23.7 \times$ $23.1(21-26 \times 21-26) \mu \mathrm{m}$ with ovoid sporocysts $14.9 \times 10.8(12-16 \times 10-12) \mu \mathrm{m}$. Only 6 of $67(9 \%)$ infected voles were found to be naturally infected with more than a single coccidium. The world literature on coccidian parasites of voles ( 1 caryosporan, 31 eimerians, 1 frankelian, 2 isosporans, 4 sarcocystans, exclusive of the 5 new species described here) was reviewed.
\end{abstract}

In an ongoing study at the University of New Mexico we are examining the evolutionary relationships of various groups of small mammals using morphologic (skin, skeleton), genetic (karyotypes, enzyme electrophoresis) and parasite (mainly coccidia) data. When the distributions and genetic relatedness of many different host species are clearly documented we may, perhaps, have a better understanding of host susceptibility, parasite burdens, host specificity (or lack thereof), and coevolutionary mechanisms. The first 2 papers on parasites reviewed the coccidia from jumping mice, Zapus spp. (Duszynski et al., 1982), and kangaroo rats, Dipodomys spp. (Stout and Duszynski, 1983). Here we review the world literature on coccidians from voles (Microtus spp.) and report 5 new species found in hosts from Japan, Mexico and the United States.

Received 2 August 1984; revised 22 January 1985; accepted 22 January 1985.

* Current address: School of Veterinary Medicine, Louisiana State University, Baton Rouge, Louisiana 70803 .

\section{MATERIALS AND METHODS}

Fecal samples were collected from hosts live-trapped in the field and stored in $2 \%(\mathrm{w} / \mathrm{v})$ aqueous potassium dichromate $\left(\mathrm{K}_{2} \mathrm{Cr}_{2} \mathrm{O}_{7}\right)$ as previously described (Duszynski et al., 1982) except that samples taken in Japan were collected and stored in $2 \%(\mathrm{v} / \mathrm{v})$ aqueous sulfuric acid $\left(\mathrm{H}_{2} \mathrm{SO}_{4}\right)$. Methods for storing and processing of fecal samples upon return to the lab and for concentrating, measuring and photographing oocysts have been described in detail (Duszynski et al., 1982; Stout and Duszynski, 1983). All measurements are in micrometers with size ranges in parentheses following the means.

\section{RESULTS}

The coccidians, the hosts they infected, and our collection localities are presented in Table I.

\section{Coccidians}

Eimeria coahuiliensis n. sp. (Figs. 1-3, 14)

\section{Description}

Oocyst ellipsoid, slightly flattened at end opposite micropyle (arrow, Fig. 1), wall $\sim 2.0(1.5-2.3)$, com- 
TABLE I. Eimeria and Isospora spp. recovered from 14 subspecies of Microtus collected from the United States, Mexico and Japan.

\begin{tabular}{|c|c|c|c|}
\hline Microtus spp. & $\begin{array}{l}\text { Country: } \\
\text { county and/or state }\end{array}$ & $\begin{array}{l}\text { No. hosts } \\
\text { infected/examined } \\
(\%)\end{array}$ & $\begin{array}{l}\text { Eimeria/Isospora identified } \\
\text { (see text) }\end{array}$ \\
\hline \multirow[t]{2}{*}{ californicus sactidiegi } & USA: & & \\
\hline & San Bernadino Co., CA & $1 / 3 \quad(33.3)$ & $\operatorname{saxel}^{*}+$ \\
\hline \multirow[t]{2}{*}{ longicaudus longicaudus } & USA: & & \\
\hline & Apache Co., AZ & $0 / 1$ & - \\
\hline \multirow[t]{2}{*}{ longicaudus macrurus } & USA: & & \\
\hline & Kittatas Co., WA & $0 / 1$ & - \\
\hline \multirow[t]{2}{*}{ mexicanus fulviventer } & Mexico: & & \\
\hline & Oaxaca & $11 / 26(42.3)$ & ochrogasteri, ${ }^{*} \dagger$ saxei, ${ }^{*} \dagger$ wenrichi, ${ }^{*} \dagger$ sp. $\ddagger$ \\
\hline \multirow{2}{*}{ mexicanus fundatus } & Mexico: & & \\
\hline & Michoacan & $1 / 2$ & sp.‡ \\
\hline \multirow{4}{*}{ mexicanus mexicanus } & Mexico: & & \\
\hline & Mexico & $5 / 14(35.7)$ & ochrogasteri, ${ }^{*} \dagger$ saxei, ${ }^{*} \dagger$ tolucadensis, ${ }^{*} \dagger \mathrm{sp} . \ddagger$ \\
\hline & Oaxaca & $1 / 2$ & sp.‡ \\
\hline & Veracruz & $7 / 15(46.7)$ & wenrichi, ${ }^{*}+$ sp.‡ \\
\hline \multirow[t]{3}{*}{ mexicanus mogollonensis } & USA: & & \\
\hline & Apache Co., AZ & $1 / 1$ & wenrichi* ${ }^{*}$ \\
\hline & Catron Co., NM & $0 / 3$ & - \\
\hline \multirow[t]{2}{*}{ mexicanus subsimus } & Mexico: & & \\
\hline & Coahuila & $22 / 48(45.8)$ & $\begin{array}{l}\text { coahuiliensis, }{ }^{*} \dagger \text { saxei, }{ }^{*} \dagger \text { subsimi, }{ }^{*} \dagger \text { wenrich } i,{ }^{*} \dagger \\
\text { sp., } \neq \text { mexicanasubsimi }{ }^{*} \dagger\end{array}$ \\
\hline \multirow[t]{2}{*}{ montanus arizonensis } & USA: & & \\
\hline & Apache Co., AZ & $5 / 8 \quad(62.5)$ & tamiasciuri, ${ }^{*} \dagger$ wenrich ${ }^{*} \dagger$ \\
\hline \multirow[t]{2}{*}{ montebelli montebelli } & Japan: & & \\
\hline & Nezano, Honshu & $6 / 6$ & spp.‡ \\
\hline \multirow[t]{2}{*}{ oregoni oregoni } & USA: & & \\
\hline & Clallam Co., WA & $2 / 4$ & saxei, ${ }^{*} \dagger$ wenrichi*† \\
\hline \multirow[t]{4}{*}{ pennsylvanicus pennsylvanicus } & USA: & & \\
\hline & Ashtabula Co., CA & $0 / 1$ & - \\
\hline & Franklin Co., MA & $5 / 11(36.4)$ & ochrogasteri, ${ }^{*}+$ wenrichi† \\
\hline & Warren Co., PA & $0 / 1$ & - \\
\hline \multirow[t]{2}{*}{ quasiater } & Mexico: & & \\
\hline & Veracruz & $0 / 1$ & - \\
\hline \multirow[t]{2}{*}{ townsendii townsendii } & USA: & & \\
\hline & Pierce Co., WA & $0 / 1$ & - \\
\hline
\end{tabular}

* New host record.

$\dagger$ New locality (state or country) record.

† Unsporulated oocysts of one (sp.) or more (spp.) morphs; unable to identify.

posed of 2 layers: inner layer membranous, colorless, outer layer rough, golden-amber, $\sim 3 / 4$ of total thickness; micropyle (arrow, Fig. 2) 2.8 and polar body (Fig. 3) present; oocyst residuum absent; sporulated oocysts $(n=46) 29.6 \times 19.6(27-34 \times 18-22)$ with L:W ratio $1.53(1.23-1.68)$; sporocysts $(\mathrm{n}=43)$ ovoid, $14.4 \times$ $8.9(13-18 \times 8-10)$ with $\mathrm{L}: \mathrm{W}$ ratio $1.59(1.36-2.01)$; Stieda body present; sporocyst residuum composed of dispersed, equatorially-located granules; each sporozoite with 2 refractile bodies. Oocysts were 168-342 days old when measured.

\section{Taxonomic summary}

Diagnosis: This eimerian does not resemble any previously described coccidian from voles.

Host: Microtus mexicanus subsimus Goldman, 1938, Museum of Southwestern Biology, Division of Mammalogy, NK 9540 (male), D. W. Moore \#1025, 24 July 1982 and NK 9542 (female), D. W. Moore \#1027, 24 July 1982.

Locality: $14.8 \mathrm{~km}$ E of San Antonio de las Alazanas, Coahuila, Mexico.
Prevalence: Found in 2 of 22 (9\%) infected $M . \mathrm{m}$. subsimus collected in San Antonio de las Alazanas.

Site of infection: Unknown, oocysts recovered from fecal contents.

Etymology: The specific name is derived from the locality of the host.

\section{Eimeria ochrogasteri Ballard, 1970}

Oocysts of this species were found in 3 of 11 (27\%) infected $M . m$. fulviventer, 2 of $13(15 \%)$ infected $M$. m. mexicanus, and 1 of $5(20 \%)$ infected $M$. p. pennsylvanicus. This species has already been well described and our observations agree with those of Ballard (1970).

\section{Eimeria saxei n. sp.}

(Fig. 11)

\section{Description}

Oocyst small-ellipsoid to subspheroid with smooth, thin wall $(<1.0)$; micropyle and oocyst residuum absent, but a polar body is present; sporulated oocysts $(n=20) 13.0 \times 11.0(11-14 \times 10-12)$ with L:W ratio 

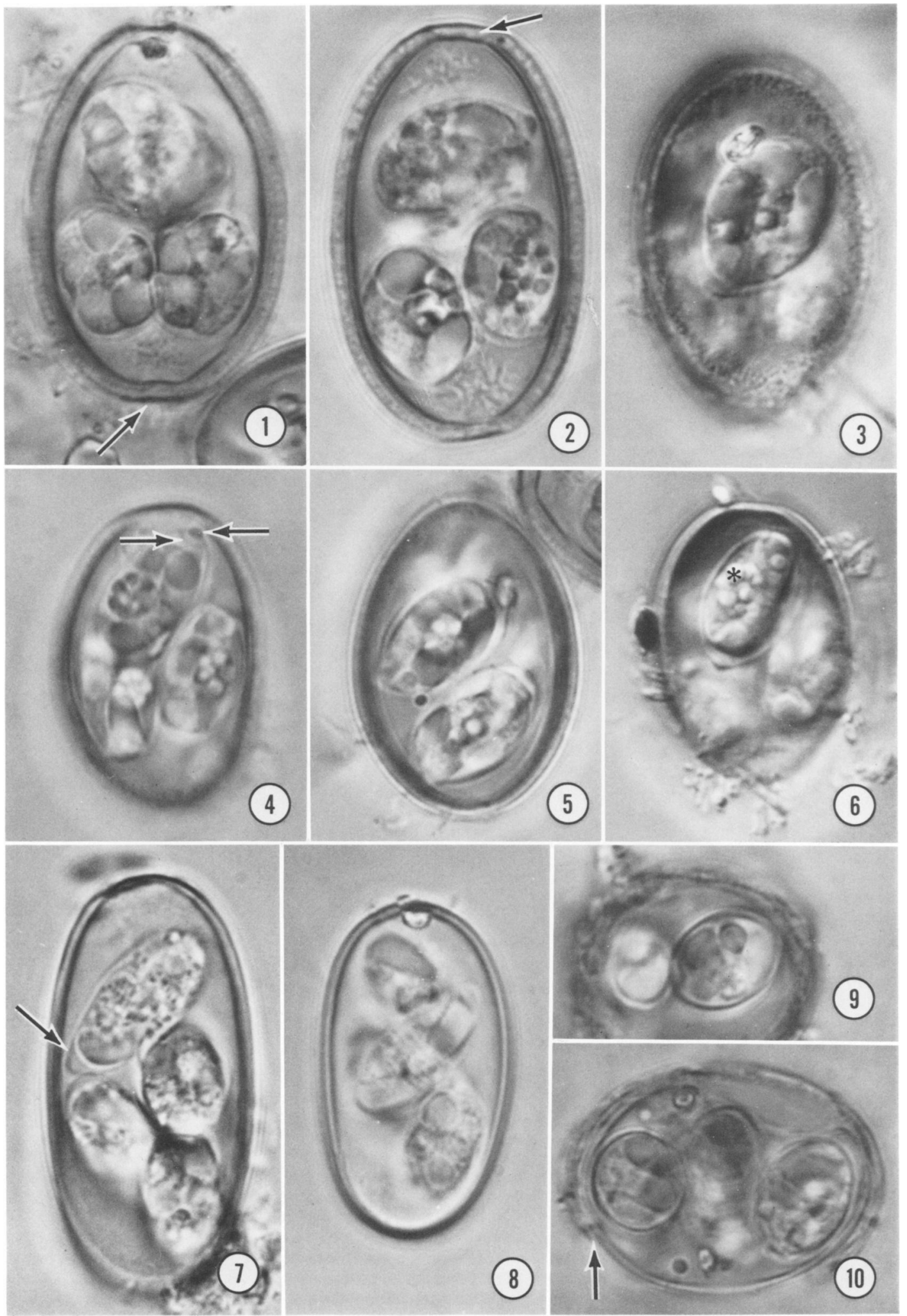
$1.18(1.10-1.40)$; sporocysts $(n=20)$ ovoid $7.5 \times 4.0$ (6-9 × 3-5) with L:W ratio 1.87 (1.50-2.25); Stieda body and compact sporocyst residuum are present. Oocysts were 418 days old when measured.

\section{Taxonomic summary}

Diagnosis: This species corresponds to the 'small form' or "Eimeria wenrichi species B" of Saxe et al. (1960). In the original description of $E$. wenrichi, the authors noted 2 distinct groups of similar oocysts that did not overlap in oocyst or sporocyst dimensions, but which otherwise shared all other structural features. In their paper, based on 87 oocysts from $1 \mathrm{M}$. pennsylvanicus, they found 56 oocysts ("species A") were $18.9 \times 14.3(16-22 \times 12-16)$ with sporocysts $9.7 \times$ $6.0(9-11 \times 5-8)$ and 31 oocysts ("species B") were $12.8 \times 9.8(11-15 \times 8-11)$ with sporocysts $6.9 \times 4.0$ $(6.5-7.5 \times 4.0)$ and concluded, ". . . the two series of oocysts ... formed completely separate populations." For some reason, however, they decided it did "not appear wise to assign them different names, even though future studies may show they differ in some other way and are actually separate species." There is certainly sufficient precedent in the literature to show that coccidians with similar structural features, but distinctly different oocyst and sporocyst dimensions, are distinct species. Many eimerians (see Duszynski, 1971 for review) are known to have oocysts that increase or decrease in size during patency. However, if this were the case with $E$. wenrichi, one would expect length-width dimensions to vary over a continuous range. In the original description, a distinct bimodal size distribution was seen and in all the hosts we saw infected with either E. wenrichi ("species A") or E. saxei ("E. wenrichi species B") oocysts were either one size or the other, with no intermediate forms. Based on these data we feel it is warranted to separate the 2 forms of $E$. wenrichi into separate species.

Type host: Microtus pennsylvanicus (Ord, 1815).

Type locality: Pennsylvania, U.S.A.

Other hosts and localities: See Table I.

Prevalence: Found in $1 \mathrm{M}$. pennsylvanicus (Saxe et al., 1960). In this study it occurred in the 1 infected M. c. sactidiegi, in 1 of 11 (9\%) infected M. m. fulviventer, in 1 of $13(8 \%)$ infected $M . m$. mexicanus, in 3 of $22(14 \%)$ infected $M$. m. subsimus, and in 1 of 2 infected $M$. o. oregoni.

Site of infection: Unknown, oocysts recovered from fecal contents.

Etymology: This parasite is named for Dr. L. H. Saxe who was senior author of the paper that first described it (Saxe et al., 1960).

\section{Eimeria subsimi n. sp.}

(Figs. 4-6, 15)

\section{Description}

Oocysts ovoid (Fig. 5) to subspheroid, wall 1.6 (1.51.8 ) with outer layer slightly sculptured comprising $~ 3 / 5$ of total thickness; polar body present, but oocyst residuum and micropyle are absent; sporulated oocysts $(\mathrm{n}=47) 25.1 \times 18.7(22-28 \times 17-21)$ with $\mathrm{L}: \mathrm{W}$ ratio $1.31(1.03-1.54)$; sporocysts $(n=45)$ ellipsoid $13.9 \times$ $7.4(13-15 \times 6-8)$ with $\mathrm{L}: \mathrm{W}$ ratio 1.93 (1.63-2.00); Stieda and substieda bodies present (arrows, Fig. 4); sporocysts contain a compact, faceted residuum (aster, Fig. 6) which may be associated with a few dispersed granules; sporozoites lie head to tail within sporocyst and contain refractile bodies. Oocysts were 155-363 days old when measured.

\section{Taxonomic summary}

Diagnosis: This species somewhat resembles $E$. iradiensis Veisov, 1963, in general size, shape and color, but differs by having oocysts that have a slightly sculptured outer wall (vs. smooth), by having a polar body, and by having longer sporocysts $(\bar{x}=14$ vs. $\bar{x}=11)$ that possess a substieda body which $E$. iradiensis lacks. Host and geographic distance may also dictate we are dealing with a new species.

Host: Microtus mexicanus subsimus Goldman, 1938, Museum of Southwestern Biology, Division of Mammalogy, NK 9515 (female), L. L. Janecek \#130, 23 July 1982 and NK 9542 (female), D. W. Moore \#1027, 24 July 1982.

Locality: $16.1 \mathrm{~km}$ E of San Antonio de las Alazanas (NK 9515), and $14.8 \mathrm{~km}$ E of San Antonio de las Alazanas (NK 9542), Coahuila, Mexico.

Prevalence: Found in 2 of 22 (9\%) infected $M . m$. subsimus collected in Coahuila, Mexico.

Site of infection: Unknown, oocysts recovered from fecal contents.

Etymology: The specific name is derived from the subspecific part of the scientific name of the host.

\section{Eimeria tamiasciuri Levine, Ivens, and Kruidenier, 1957}

(Figs. 7 and 8)

\section{Description}

Oocyst elongate ellipsoid, smooth wall $\sim 1.0$, appears single-layered; a polar body, sometimes (11\%) associated with one pole (Fig. 8), is present but a micropyle and oocyst residuum are lacking; sporulated oocysts $(n=104) 30.3 \times 17.1(23-37 \times 13-19)$ with L:W ratio $1.80(1.60-2.55)$; sporocysts $(\mathrm{n}=102)$ ellipsoid $14.8 \times$ $6.7(10-17 \times 6-8)$ with $\mathrm{L}: \mathrm{W}$ ratio $2.18(1.60-2.80)$; a

FIGURES 1-10. Photomicrographs of sporulated oocysts of coccidians recovered from the feces of Microtus spp. $\times 1,840.1-3$. Eimeria coahuiliensis n. sp. from $M$. m. subsimus. 1. Flattened end (arrow) opposite micropyle. 2. Micropyle (arrow). 3. Note polar body. 4-6. Eimeria subsimi n. sp. from $M$. m. subsimus. 4. Stieda and substieda bodies (arrows). 5. Note polar body and ovoid shape. 6. Faceted sporocyst residuum (*). 7, 8. Eimeria tamiasciuri Levine, Ivens, and Kruidenier, 1957. 7. Conical Stieda body (arrow). 8. Note variation in size of oocysts and terminal location of polar body in some oocysts. 9, 10. Eimeria tolucadensis $\mathrm{n}$. sp. from $M$. $m$. mexicanus. 9. Ellipsoid sporocyst and its residuum. 10. Fragmented piece of oocyst outer wall (arrow). 

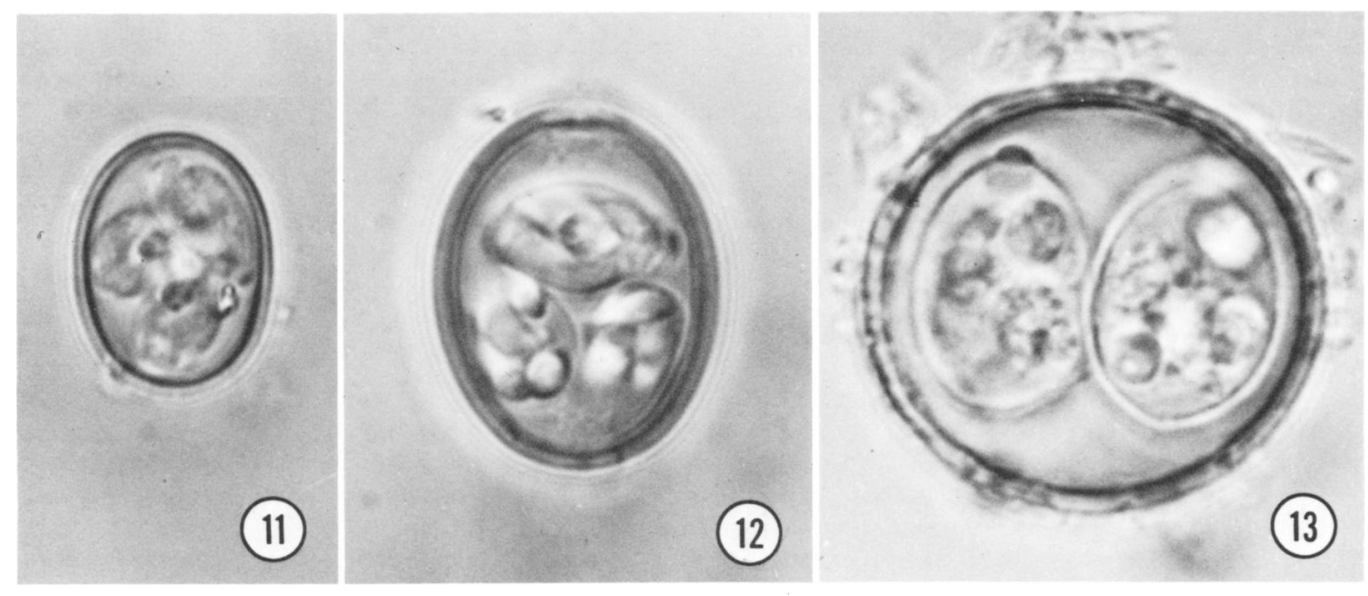

FIGURES 11-13. Photomicrographs of sporulated oocysts of coccidians recovered from the feces of Microtus spp. $\times 1,840$. 11. Eimeria saxei n. sp. from M. c. sactidiegi. 12. Eimeria wenrichi Saxe, Levine, and Ivens, 1960 from $M . m$. subsimus. 13. Isospora mexicanasubsimi n. sp. from $M$. $m$. subsimus; note prominent substieda body (arrow).

prominent, conical Stieda body (arrow, Fig. 7) and a finely granular, dispersed sporocyst residuum are present; sporozoites with at least 1 refractile body each. Oocysts were 97 days old when measured.

\section{Taxonomic summary}

Diagnosis: Oocysts of this parasite do not resemble those from any eimerian reported from voles and our initial thought was to describe it as new. However, the geographic range of the red squirrel Tamiasciuris hudsonicus mogollonensis in Arizona completely overlaps the limited distribution of $M . m$. arizonensis in eastcentral Arizona (Hall, 1981a, 1981b). Levine et al. (1957) described E. tamiasciuri oocysts from the red squirrel, T. h. mogollonensis, in Arizona and the oocysts we found in $M . m$. arizonensis from eastern Arizona are indistinguishable from them. They are also indistinguishable from E. tamiasciuri oocysts we have recovered from chipmunks (Eutamias spp.) in Arizona, California and Mexico (unpubl.). Although oocysts were found in large numbers in our infected vole, this may be a spurious finding since only 1 Arizona vole was found to harbor them. On the other hand, until crosstransmission studies can prove otherwise, E. tamiasciuri may be a valid parasite of Microtus.

Host: Microtus montanus arizonensis Bailey, 1898, Museum of Southwestern Biology, Division of Mammalogy, MSB 53569 (male), D. W. Moore \#1179, 24 September 1983.

Locality: $25.7 \mathrm{~km} \mathrm{W,} 6.4 \mathrm{~km}$ S Alpine, TSN R28E, SW 1/4 sec. 29, Westfork Campground, Apache Co., Arizona.

Prevalence: Found in 1 of $5(20 \%)$ infected $M . m$. arizonensis collected from Apache Co., Arizona.

Site of infection: Unknown, oocysts recovered from fecal contents.

\section{Eimeria tolucadensis n. sp. (Figs. 9, 10, 16) \\ Description}

Oocysts subspheroid or nearly so, wall 2.3 (2-3) with outer, multilaminar layer comprising $\sim 2 / 3$ of total thick- ness (Fig. 10); inner layer smooth; 1 or more polar bodies present, but micropyle and oocyst residuum are absent; sporulated oocysts $(n=11) 25.4 \times 20.3(23-$ $26 \times 19-23)$ with L:W ratio $1.25(1.15-1.40)$; sporocysts $(\mathrm{n}=11)$ ellipsoid $11.3 \times 7.8(10-13 \times 7-9)$ with $\mathrm{L}: W$ ratio 1.44 (1.26-1.70); an inconspicuous Stieda body is present (Fig. 9), but not a substieda body; sporocyst residuum present and consists of 4 to 6 small globules; sporozoites contain 1 or 2 refractile bodies. Oocysts were 313 days old when measured.

\section{Taxonomic summary}

Diagnosis: Oocysts of this species do not fit the description of oocysts from any eimerian previously described from voles; they are similar, however, to $E$. baiomys Levine, Ivens, and Kruidenier, $1958 \mathrm{de}-$ scribed from Baiomys taylori (Thomas), which shares a common habitat range, Michoacan to Veracruz, with $M$. m. mexicanus (Hall, 1981b), except that $E$. baiomys is proportionally smaller, has a single-layered oocyst wall and contains a conspicuous oocyst residuum which is missing in E. tolucadensis.

Host: Microtus mexicanus mexicanus (Saussure, 1861), Museum of Southwestern Biology, MSB 48299 (female), L. L. Janecek \#192, 5 August 1982.

Locality: $17.5 \mathrm{~km} \mathrm{~S}, 7.0 \mathrm{~km} \mathrm{~W}$ of Toluca, Nevado de Toluca, Mexico, Mexico.

Prevalence: Found in 1 of $5(20 \%)$ infected $M . m$. mexicanus collected from Toluca, Nevado de Toluca, Mexico, Mexico.

Site of infection: Unknown, oocysts recovered from fecal contents.

Etymology: The specific name is derived from the locality where the infected host was collected.

\section{Eimeria wenrichi Saxe, Levine, and Ivens, 1960} (Fig. 12)

\section{Description}

Oocysts of this species were seen in 1 of $11(9 \%)$ infected $M . m$. fulviventer, 4 of $13(31 \%)$ infected $M$. $m$. mexicanus, the only infected $M . m$. mogollonensis, 

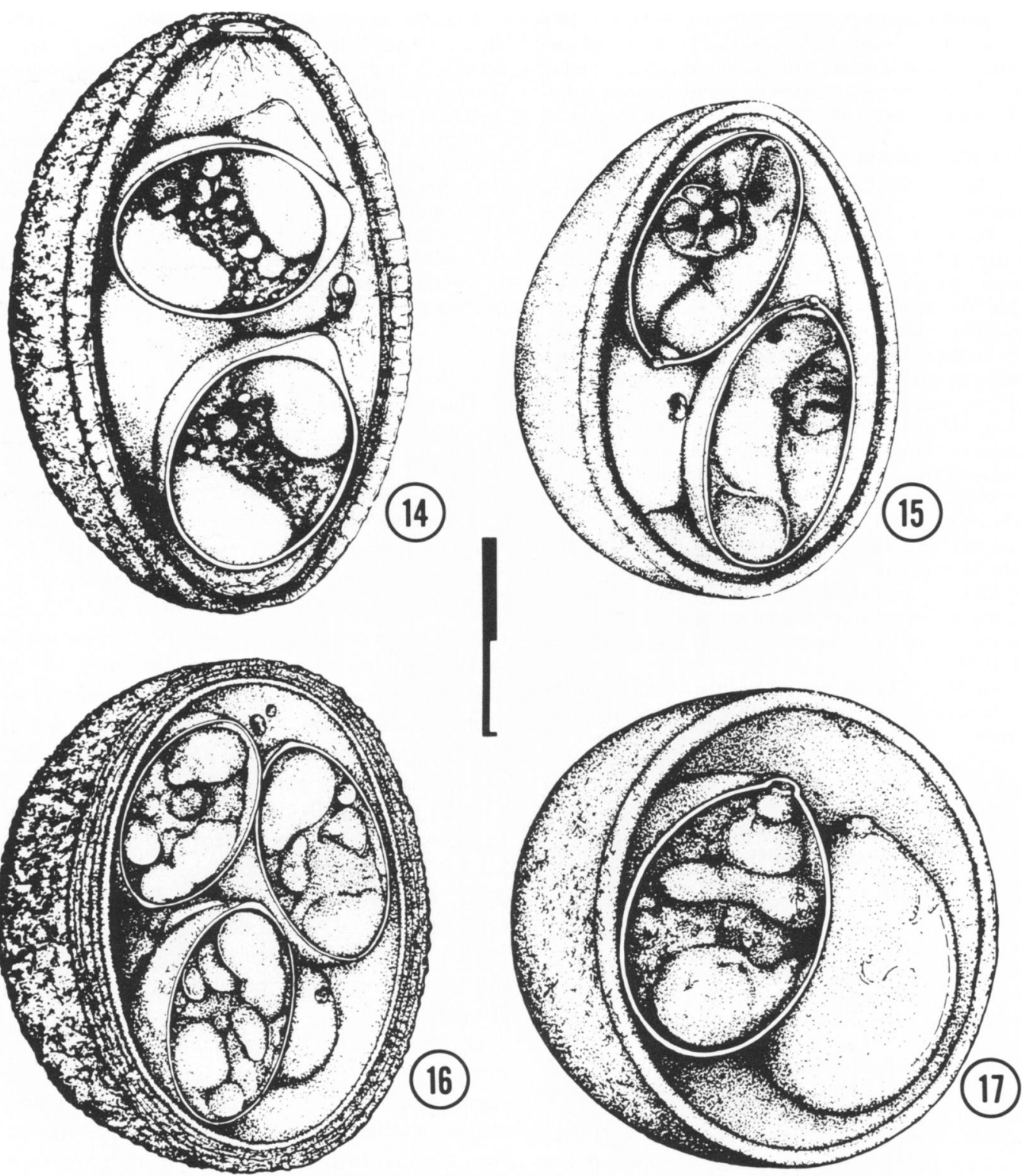

FIGURES 14-17. Line drawings of sporulated oocysts of new coccidian species recovered from the feces of Microtus spp.; scale $=10 \mu \mathrm{m}$. 14. Eimeria coahuiliensis. 15. Eimeria subsimi. 16. Eimeria tolucadensis. 17. Isospora mexicanasubsimi.

8 of $22(36 \%)$ infected $M$. m. subsimis, 4 of $5(80 \%)$ infected $M . m$. arizonensis, both infected $M$. o. oregoni, and all 5 infected M. p. pennsylvanicus. Photomicrographs of this species have not been published previously, so 1 is included (Fig. 12). All oocysts that we identified as $E$. wenrichi fit the description for the 'large form' or " $E$. wenrichi species A" in the original description by Saxe et al. (1960) (for explanation, see Diagnosis section for $E$. saxei, above).

\section{Isospora mexicanasubsimi n. sp.}

(Figs. 13 and 17)

\section{Description}

Oocyst spheroid or nearly so, wall $\sim 1.5$, bilayered with a lightly pitted outer surface and a smooth, somewhat darker inner layer; sporulated oocysts $(n=10)$ $23.7 \times 23.1(21-26 \times 21-26)$ with $\mathrm{L}: \mathrm{W}$ ratio 1.03 (1.00-1.13); micropyle, oocyst residuum, and polar 
body absent; sporocysts $(n=10)$ ovoid $14.9 \times 10.8$ $(12-16 \times 10-12)$ with L:W ratio $1.38(1.26-1.61)$; sporocysts possess distinct Stieda and substieda bodies (Fig. 13) as well as a dispersed, homogeneous residuum. Oocysts were 198-213 days old when measured.

\section{Taxonomic summary}

Diagnosis: Only 2 isosporans have been reported as parasites of the genus Microtus, I. mcdowelli Saxe et al., 1960 from M. pennsylvanicus and I. arvalis Mikeladze, 1974 reported from $M$. arvalis. Two other species, though, have been reported from hosts also within the family Arvicolidae. These are: I. laguri Iwanoff-Gobzen, 1934 and I. teres Iwanoff-Gobzem, 1934 reported from Lagurus lagurus (Pallas). The coccidian described herein did not resemble these previously reported species.

Host: Microtus mexicanus subsimus Goldman, 1938, Museum of Southwestern Biology, Division of Mammalogy, MSB 48337 (female), L. L. Janecek \#121, 23 July 1982 and MSB 48332 (female), L. L. Janecek \#149, 23 July 1982.

Locality: $16.1 \mathrm{~km}$ E of San Antonio de las Alazanas, Coahuila, Mexico.

Prevalence: Found in 2 of 22 (9\%) infected $M . \mathrm{m}$. subsimus collected from Coahuila, Mexico.

Site of infection: Unknown, oocysts recovered from fecal contents.

Etymology: The specific name is derived from the specific and subspecific parts of the scientific name of the host.

\section{Hosts}

Of those hosts with coccidia at the time they were collected, the following parasites, or groups of parasites were seen.

Microtus californicus sactidiegi Kellogg, 1918. The 1 infected vole of this species had oocysts of $E$. saxei in its feces.

Microtus mexicanus fulviventer Merriam, 1898. All 11 infected voles were singly-infected with either $E$. ochrogasteri (3), E. saxei (1), E. wenrichi (1), or Eimeria sp. (6).

Microtus mexicanus fundatus Hall, 1948. The only infected vole was singly-infected with unsporulated oocysts of a single morph.

Microtus mexicanus mexicanus (Saussure, 1861). We found 12 of $13(92 \%)$ infected voles singly-infected with either E. ochrogasteri (1), E. saxei (1), E. wenrichi (4), or Eimeria sp. (6); 1 vole harbored 2 coccidians: $E$. ochrogasteri and E. tolucadensis.

Microtus mexicanus mogollonensis (Mearns, 1890). The only infected vole was singly-infected with $E$. wenrichi.

Microtus mexicanus subsimus Goldman, 1938. Nineteen of $22(86 \%)$ infected voles were singly-infected with either E. coahuiliensis (1), E. saxei (2), E. wenrichi (5), I. mexicanasubsimi (2), or Eimeria sp. (9); 2 voles were doubly-infected, 1 with $E$. wenrich $i$ and $E$. saxe $i$ and 1 with $E$. wenrich $i$ and $E$. subsimi; 1 vole was infected with 3 species, $E$. coahuiliensis, $E$. subsimi, and $E$. wenrichi.

Microtus montanus arizonensis Bailey, 1898. All 5 infected voles were singly-infected with either E. tamiasciuri (1) or E. wenrichi (4).
Microtus montebelli montebelli (Milne-Edwards, 1872). All 6 infected voles had oocysts that never sporulated. Four of $6(67 \%)$ had oocysts of only a single morph; the other 2 infected hosts had oocysts of 2 distinctly different morphs.

Microtus oregoni oregoni (Bachman, 1839). One of 2 infected voles was singly-infected with $E$. wenrichi, the other was doubly-infected with $E$. saxei and $E$. wenrichi.

Microtus pennsylvanicus pennsylvanicus (Ord, 1815). Four of $5(80 \%)$ infected voles were singly-infected with $E$. wenrichi; 1 infected vole was infected with both $E$. ochrogasteri and E. wenrichi.

\section{DISCUSSION}

The majority of the literature on the Coccidia of voles (Microtus spp.) originates from Eurasian sources, which describe 29 eimerians, 1 isosporan, and 2 sarcocystans; in North America, only 7 species (Caryospora microti, Frenkelia microti, Eimeria orchogasteri, E. wenrichi "A" and "B," Isospora mcdowelli, Sarcocystis microti and $S$. montanaensis) have been reported prior to the species we describe here (Table II). According to recent taxonomic schemes (Honacki et al., 1982), Microtus is the most specious of 20 genera assigned to the family Arvicolidae. In addition to the 39 coccidians described previously from $\mathrm{Mi}$ crotus spp., 6 other genera in the family (Alticola, Cleithrionomys, Discrostonyx, Ellobius, Lagurus, Ondatra) have been identified as hosts of at least 17 additional coccidian species (Levine, 1951; Levine and Ivens, 1965; Pellérdy, 1974; Golemansky, 1979). None of the 56 coccidians previously described from arvicolids resembled the new species described here, other than the similarities already noted.

On the other hand, as we measure and identify numerous coccidians from thousands of specimens of both closely related and unrelated mammalian species, we are beginning to see oocysts that are identical or nearly so from genetically unrelated, but geographically sympatric host species. For example, here we point out that oocysts of E. tamiasciuri, originally described from the red squirrel ( $T . h$. mogollonensis) were also found in large numbers in a $M . m$. arizonensis and in several groups of chipmunks (unpubl.). Also in our work with other genera of small mammals we have seen more substantive examples of oocysts described from one host genus commonly found in the feces of unrelated hosts (e.g., Perognathus and Dipodomys spp.; Peromyscus and Neotoma spp.; and others, unpubl. data). Obviously, there is much crosstransmission work to be done before such prob- 
TABLE II. Coccidian parasites of Eurasian and North American Microtus spp. described to date.

\begin{tabular}{|c|c|c|}
\hline Coccidian spp. & Microtus spp. & Reference used \\
\hline Caryospora microti & pennsylvanicus & Saxe et al., 1960 \\
\hline Eimeria abuschevi & majori & Veisov, 1962 \\
\hline E. arvicolae & arvalis, nivalis & Veisov, 1963 \\
\hline E. bicrustae & majori & Veisov, 1962 \\
\hline E. chetae & middendorfii & Arnastauskene, 1980 \\
\hline E. chudatica & socialis & Musaev et al., 1963 \\
\hline E. coahuiliensis & mexicanus & present study \\
\hline E. correptionis & majori & Veisov, 1962 \\
\hline E. cubinica & socialis & Musaev et al., 1963 \\
\hline E. cusarica & socialis & Musaev et al., 1963 \\
\hline E. derenica & arvalis & Veisov, 1963 \\
\hline E. dzulfaensis & socialis & Pellérdy, 1974 \\
\hline E. gomurchaica & arvalis & Veisov, 1963 \\
\hline E. guentherii & guentheri & Golemansky, 1978 \\
\hline E. hadrutica & socialis & Musaev et al., 1963 \\
\hline E. iradiensis & arvalis & Veisov, 1963 \\
\hline E. iwanoffi & arvalis & Veisov, 1963 \\
\hline E. kolabski & socialis & Pellérdy, 1974 \\
\hline E. kolanica & arvalis & Veisov, 1963 \\
\hline E. kotuji & middendorfii & Arnastauskene, 1980 \\
\hline E. luteola & middendorfi & Arnastauskene, 1980 \\
\hline E. majorici (syn. E. arvalis) & majori & Veisov, 1962 \\
\hline E. micropiliana & socialis & Musaev et al., 1963 \\
\hline E. microtina & socialis & Pellérdy, 1974 \\
\hline E. middendorfi & middendorfii & Arnastauskene, 1977 \\
\hline E. monocrustae & arvalis & Veisov, 1963 \\
\hline E. ochrogasteri & $\begin{array}{l}\text { ochrogasteri, mexicanus, } \\
\text { pennsylvanicus }\end{array}$ & $\begin{array}{l}\text { Ballard, 1970, present } \\
\text { study }\end{array}$ \\
\hline E. pitymydis & Pitymys subterraneus* & Golemansky, 1979 \\
\hline E. primbelica & arvalis & Veisov, 1963 \\
\hline E. schelkovnikovi & schelkovnikovi & Musaev, 1967 \\
\hline E. saxei (syn. E. wenrichi "B") & californicus, mexicanus, oregoni & present study \\
\hline E. subsimi & mexicanus & present study \\
\hline E. taimyrica & middendorfii & Arnastauskene, 1977 \\
\hline E. tamiasciuri & montanus & present study \\
\hline E. tolucadensis & mexicanus & present study \\
\hline E. wenrichi (syn. E. wenrichi "A") & pennsylvanicus & Saxe et al., 1960 \\
\hline E. zuvandica & arvalis & Veisov, 1963 \\
\hline Frenkelia microti & agrestis & Biocca, 1968 \\
\hline Isospora arvalis & arvalis & Mikeladze, 1974 \\
\hline I. mcdowelli & pennsylvanicus & Saxe et al., 1960 \\
\hline I. mexicanasubsimi & mexicanus & present study \\
\hline Sarcocystis cernae & arvalis & Levine, 1977 \\
\hline S. microti & pennsylvanicus & Dubey, 1983 \\
\hline S. montanaensis & pennsylvanicus & Dubey, 1983 \\
\hline S. putorii & arvalis, agrestis & Tadros and Laarman, 1978 \\
\hline
\end{tabular}

* According to Nowak and Paradisio (1983) Pitymys is now a subgenus of Microtus.

lems as host specificity can be addressed in these instances, but perhaps a lack of host specificity among eimerians, such as that seen by de Vos (1970), for $E$. chinchillae, is more widespread than we suspect. It is also likely that geographic and ecologic factors play much more of an important role in host-specificity than previously given credit.

It seems axiomatic that certain groups of mammals would be at greater risk of infection by coccidians than other mammalian groups simply because of the natural environments in which they live. For example voles, which live in mesic grasslands should have a higher incidence of infection with coccidians than say kangaroo rats (Dipodomys spp.) which live in xeric environments simply because the former environments (grassland) would be more conducive to oocyst survival than the latter (desert). At least some support for this generalization is available. In a previous study (Stout and Duszynski, 1983) only 104 of 361 (29\%) kangaroo rats (7 species, 13 collection localities) harbored coccidia when examined; whereas in the present study 67 of 149 (45\%) voles (9 species, 15 collection localities) had oocysts in their feces when examined. 
When we examine the individual infected animals in this and our other recent surveys we see that a very high percentage of infected hosts had only one coccidian species when examined. In Zapus spp. (Duszynski et al., 1982) 29 of 29 (100\%) infected hosts, in Dipodomys spp. (Stout and Duszynski, 1983) 88 of $104(85 \%)$ infected hosts, in Peromyscus spp. (Reduker et al., 1985) 97 of 106 (92\%) infected hosts, and in Microtus spp. (this study) 61 of 67 (91\%) infected hosts had only single species infections when examined. This may indicate there is strong selective advantage for certain host groups to maintain only one coccidian species at any one time. It will be interesting to learn if this observation is consistent from host to host as more data become available.

It should be noted that all oocysts recovered from the feces of $M$. m. montebelli were deteriorated and/or unsporulated when examined. Samples taken from this host species were stored and processed in $2 \%(\mathrm{v} / \mathrm{v})$ aqueous $\mathrm{H}_{2} \mathrm{SO}_{4}$; though others (Frenkel and Dubey, 1975; Ruiz and Frenkel, 1980) have used $2 \% \mathrm{H}_{2} \mathrm{SO}_{4}$ to sporulate and store coccidian oocysts (e.g., Hammondia, Isospora, Toxoplasma), it has been our experience in this and previous field collections that $\mathrm{H}_{2} \mathrm{SO}_{4}$, when used for any long period as a storage medium, is detrimental to the survival and structural integrity of eimerian oocysts.

Finally, we note that 3 of the new species we describe, E. coahuiliensis, $E$. subsimi and $I$. mexicanasubsimi were all parasites in a unique karyotypic race, Microtus mexicanus subsimus, that is found only in our northernmost collection locality of Mexico, San Antonio de las Alazanas. All voles collected in this area had diploid numbers of 44 whereas all other voles taken in Mexico had diploid numbers of 48 (Moore, pers. comm.). Alterations in chromosomes, and the subsequent amino acid sequencing, may produce slight changes in metabolic pathways or enzyme properties to change a host's gastrointestinal physiology. Certain coccidians then might be more likely to establish, others might be rejected, while still others might be stimulated to undergo a speciation event.

\section{ACKNOWLEDGMENTS}

This study was supported by HHS NIH grant RR-08139 and, in part, by NSF grant DEB8004685. We are indebted to the following students and staff in the Department of Biology,
The University of New Mexico, for their help in the collection and/or processing of voles: $L$. $L$. Janecek, D. W. Moore, S. L. Gardner and C. A. Stout. The major trip to Mexico during which many of the hosts in this study were collected was supported by a grant from Sigma Xi to D. W. Moore. Thanks to D. W. Moore also for providing information and comments on the genetic relatedness of subspecies of $M$. mexicanus and to Dr. Norman D. Levine, The University of Illinois for helping retrieve some of the Russian literature and for giving us access to pertinent sections of the 2nd edition of The Coccidian Parasites of Rodents (in press).

\section{LITERATURE CITED}

Arnastauskene, T. V. 1977. K voprosy o zarazhennosti zhivitnykh Koktsidiyami na Taimyre. In Problemy Epidemiologii i Profilaktiki Prirodnoochagovykh Boleznei v Zapolyar'e. G. V. Kornulova, V. K. Yastrebov and V. A. Klebanevskii (eds.). Ministerstvo Zdravookhraneniya RSFSR, Omskii Ordena Trudovogo Krasnogo Znameni Meditsinskii Institut, Omsk, U.S.S.R., pp. 135143.

- 1980. Characteristics of the infections of small mammals with coccidia in the Taimyr Peninsula Russian, SFSR, USSR, in 1974-1975 (text in Russian). Trudy Akademaii Nauk Litovskoi SSR, Seriia B 2(90): 53-60.

BAllaRd, N. B. 1970. Eimeria ochrogasteri n. sp. from the prairie vole, Microtus ochrogaster. Journal of Protozoology 17: 271-273.

BioccA, E. 1968. Class Toxoplasmatea: Critical review and proposal of the new name Frenkelia gen. n. for M-organism. Parasitologia 10: 89-99.

DE VOS, A. J. 1970. Studies on the host range of Eimeria chinchillae de Vos and Van der Westhuizen, 1968. Onderstepoort Journal of Veterinary Research 37: 29-36.

DuBEY, J. P. 1983. Sarcocystis montanaensis and $S$. microti sp. $\mathrm{n}$. from the meadow vole (Microtus pennsylvanicus). Proceedings of the Helminthological Society of Washington 50: 318-324.

DUSZYNSKI, D. W. 1971. Increase in size of Eimeria separata oocysts during patency. Journal of Parasitology 57: 948-952.

, G. EASTHAM, AND T. L. YATES. 1982. Eimeria from jumping mice (Zapus spp.): A new species and genetic and geographic features of $Z$. hudsonicus luteus. Journal of Parasitology 68: 1146-1 148.

Frenkel, J. K., AND J. P. DubeY. 1975. Hammondia hammondigen. nov., sp. nov., from domestic cats, a new coccidian related to Toxoplasma and Sarcocystis. Zeitschrift für Parasitenkunde 46: 3-12.

Golemansky, V. G. 1978. Description de neuf nouvelles espéces de coccidies (Coccidia: Eimeriidae), parasites de micromammiferes en Bulgarie. Acta Protozoologica 17: 261-270.

- 1979. Coccidia (Coccidia, Eimeriidae) of mammals from the Parangalista, Ropotamo and 
Srebarna reserves in Bulgaria. Acta Zoologica Bulgarica 0(12): 12-26.

HALl, E. R. 1981a. The mammals of North America, 2nd ed., Vol. I. John Wiley and Sons, New York, pp. 443-444.

. 1981b. The mammals of North America, 2nd ed., Vol II. John Wiley and Sons, New York, pp. 725-726, 797-798, 814-815.

HoNACKI, J. H., K. E. KinMan, AND J. W. KoEPPL. 1982. Mammal species of the world. Allen Press, Inc. \& the Assoc. of Systematic Collections, Lawrence, Kansas, 694 p.

LeVINE, N. D. 1951. Eimeria dicrostonicis n. sp., a protozoan parasite of the lemming, and other parasites from arctic rodents. Transactions of the Illinois Academy of Sciences 44: 205-208.

- 1977. Sarcocystis cernae sp. n. replacement name for Sarcocystis sp. Cerna \& Louckova, 1976. Folia Parasitologica (Praha) 24: 316.

- AND V. IvENS. 1965. The coccidian parasites (Protozoa, Sporozoa) of rodents. Illinois Biological Monograph No. 33. 365 p.

, AND F. J. KRUIDENIER. 1957. New species of Eimeria from Arizona rodents. Journal of Protozoology 4: 80-88.

- $\longrightarrow$, AND —. 1958 (1957). New species of Eimeria (Protozoa: Eimeriidae) from Mexican rodents. Transactions of the Illinois Academy of Sciences 50: 291-298.

MikeladZe, L. G. 1974 (1973). A new species of Coccidia, Isospora arvalis, new species from the common field mouse, Microtus arvalis (text in Russian). Soobshcheniya Akademii Nauk Gruzinskoi SSR 72: 477-479.

Musaev, M. A. 1967. A new species of coccidia of the genus Eimeria from the field mouse Microtus (Pitymys) schelkovnikovi, Eimeria schelkovnikovi new species (text in Russian). Izvestiya Akademii Nauk Azerbaidzhanskoi SSR Seriya Biologicheskikh I Nauk 1: 44-46.
A. M. Veisov, AND F. K. Alieva. 1963. Five new coccidian species of the genus Eimeria from Microtus socialis Pallas (text in Russian). Zoologicheskii Zhurnal U.S.S.R. 42: 809-813.

NowaK, R. M., AND J. L. PARAdISO. 1983. Walker's mammals of the world, Vol. 1. Johns Hopkins University Press, Baltimore, $568 \mathrm{p}$.

Pellérdy, L. P. 1974. Coccidia and coccidiosis, 2nd ed. Verlag. Paul Parey, Berlin, 959 p.

ReduKer, D. W., L. HERTEL, AND D. W. DuszYNSKI. 1985. Eimeria spp. (Apicomplexa: Eimeriidae) infecting Peromyscus rodents in the southwestern United States and northern Mexico with description of a new species. Journal of Parasitology 71: (in press).

Ruiz, A., AND J. K. Frenkel. 1980. Toxoplasma gondii in Costa Rican cats. American Journal of Tropical Medicine and Hygiene 29: 1150-1160.

SAXE, L. H., N. D. LEVINE, AND V. IvENS. 1960. Species of Coccidia from the meadow mouse, Microtus pennsylvanicus. Journal of Protozoology 7: 61-63.

Stout, C. A., AND D. W. DuszYNSKI. 1983. Coccidia from kangaroo rats (Dipodomys spp.) in the western United States with descriptions of Eimeria merriami sp. n. and Isospora sp. Journal of Parasitology 69: 209-214.

TADros, W., AND J. J. LAARMAN. 1978. A comparative study of the light and electron microscopic structure of the walls of the muscle cysts of several species of sarcocystid eimeriid Coccidia: II. Proceedings of the Koninklijke Nederlandse Akademie van Wetenschappen, Series $C$, Biological and Medical Sciences, Netherlands 81: 486-491.

Veisov, A. M. 1962. New species of Eimeria from the shrub vole of Asia Minor Microtus majori Thomas, 1906 (text in Russian). Doklady Akademii Nauk Azerbaidzhanskoi SSR 18: 59-64. . 1963. Coccidia of Microtus arvalis Pallas 1778 in Azerbaidzhane (text in Russian). Izvestiya Akademii Nauk Azerbaidzhanskoi SSR 4: 61-76. 